\title{
THE INFLUENCE OF THE BOARD OF DIRECTORS AND THE AUDITOR IN THE DISCLOSURE OF DERIVATIVE FINANCIAL INSTRUMENTS: EVIDENCE ON PORTUGUESE CAPITAL MARKET
}

\author{
ASara Serra, BKátia Matos Lemos, \\ cMaria Sofia Matins
}

\begin{tabular}{|c|c|}
\hline \multirow{2}{*}{ ARTICLE INFO } & \multirow{4}{*}{$\begin{array}{l}\text { ABSTRACT } \\
\text { Purpose: This article aims to analyze the influence of certain characteristics of the board } \\
\text { of directors and the auditor on the disclosure of derivative financial instruments. } \\
\text { Theoretical framework: Opera tions with derivative instruments are a ssociated with high } \\
\text { risks, so the disclosure of these operations and their results helps to reduce information } \\
\text { a symmetries. On the other hand, acccording to agency theory, the characteristics of the } \\
\text { board of directors and of the auditor can affect the quality and the level of financial } \\
\text { information disclosed. }\end{array}$} \\
\hline & \\
\hline $\begin{array}{l}\text { Article history: } \\
\text { Received } 01 \text { June } 2021 \\
\text { Accepted } 17 \text { October } 2021\end{array}$ & \\
\hline \multirow{6}{*}{$\begin{array}{l}\text { Keywords: } \\
\text { Auditor, Board of Directors, } \\
\text { Listed Companies, } \\
\text { Disclosure Index, } \\
\text { Derivative financial instruments. }\end{array}$} & \\
\hline & $\begin{array}{l}\text { Design/methodology/approach: The data were obtained through content analysis, } \\
\text { considering the } 2017 \text { reports and accounts of } 37 \text { companies listed on Euronext Lisbon, } \\
\text { through a disclosure index. Subsequently, a multiple linear regression model was developed } \\
\text { to identify the determinants of the level of disclosure about derivative instruments. }\end{array}$ \\
\hline & $\begin{array}{l}\text { Findings: The results revea led that only the number of independent members on the board } \\
\text { of directors, the auditor's gender, and the size of the entity influence the level of disclosure } \\
\text { about derivative instruments. }\end{array}$ \\
\hline & $\begin{array}{l}\text { Research, Practical \& Social implications: This study may be useful for regulators in } \\
\text { setting disclosure requirements for derivative instruments and useful in companies' decision } \\
\text { making in defining the members of the board and the auditor. }\end{array}$ \\
\hline & $\begin{array}{l}\text { Originality/value: It contributes to the litera ture on compliance with IFRS and contributes } \\
\text { to the perception of the influence of certain characteristics a ssociated with the board of } \\
\text { directors and the auditor in the disclosure of derivativeinstruments. }\end{array}$ \\
\hline & Doi: https://doi.org/10.26668/businessreview/2022.v7i1.240 \\
\hline
\end{tabular}

\footnotetext{
${ }^{A}$ Doctor of Accounting from University of Minho, Portugal. She is an Adjunct Professor at the Escola Superior de Gestão, at the Polytechnic Institute of Cávado and Ave (Barcelos), Portugal. Email: sserra@ipca.pt Orcid: https://orcid.org/0000-0003-3107-1752
}

B Doctor of Accounting from University of Santiago de Compostela, Spain. She is an Adjunct Professor at the Escola Superior de Gestão, at the Polytechnic Institute of Cávado and Ave (Barcelos), Portugal. Email: klemos@ipca.pt

Orcid: https://orcid.org/0000-0002-3961-5964

C Master Student, School of Management, Institute Polytechnic of Cávado and Ave (Barcelos), Portugal. Email: a9621@alunos.ipca.pt

Orcid: https://orcid.org/0000-0002-1095-0726 


\section{LA INFLUENCIA DEL CONSEJO DE ADMINISTRACIÓN Y DEL AUDITOR EN LA DIVULGACIÓN DE INSTRUMENTOS FINANCIEROS DERIVADOS: EVIDENCIA SOBRE EL MERCADO DE CAPIT ALES PORTUGUÉS}

Objetivo: Este artículo tiene como objetivo a nalizar la influencia de determinadas características del consejo de a dministración y del auditor en la divulga ción de los instrumentos financieros derivados.

Método: Los da tos se obtuvieron mediante a nálisis de contenido, considerando los informes y cuentas de 2017 de 37 empresas cotizadas en EuronextLisboa, a través de uníndice de divulga ción. Posteriormente, se desarrolló un modelo de regresión lineal múltiple para identificar los determinantes del nivel de divulgación sobre instrumentos derivados.

Originalidad / Relevancia Las operaciones con instrumentos derivados están asociadas a altos riesgos, por lo que la divulga ción de estas operaciones y sus resulta dos a yuda a reducir las a simetrías de información. Por otro la do, según la teoría de la a gencia, la s características del consejo de administración y del auditor pueden afectar la calidad y el nivel de la información financiera divulga da.

Resultados (obligatorio): Los resultados revelaron que solo el número de miembros independientes en el consejo de administración, el género del auditor y el tamaño de la entidad influyen en el nivel de divulgación sobre los instrumentos derivados.

Contribuciones teóricas / metodológicas: Este estudio puede ser útil para que los reguladores establezcan requisitos de divulga ción para instrumentos derivados y útil en la toma de decisiones de las em presas para definir los miembros del consejo y el auditor.

Contribuciones sociales / gerenciales: Contribuye a la litera tura sobre el cumplimiento de las NIIF y contribuye a la percepción de la influencia de determinadas características asociadas al consejo de administración y al auditor en la divulga ción de instrumentos derivados.

Palabras clave: Auditor, Consejo de Administración, Sociedades Cotizadas, Índice de Divulgación, Instrumentos Fina nciero Derivados

\section{INTRODUCTION}

Financial markets, among other things, help investors to diversify part of their risk and offer financial instruments with different risk-return ratios, allowing them to choose the most suitable risk profile for their applications. So that users of financial information be able to make correct decisions, they must have sufficient and reliable information. As so, there has been a great concern with the levels of disclosure, both quantitative and qualitative, with companies seeking to meet the demands of their users.

The disclosure of information about transactions with derivative instruments has been the subject of intense debate at an international level, and regulatory bodies have shown concern with the definition of the minimum disclosure requirements.

The disclosure on derivative instruments reduces information asymmetries, contributes to the reduction of capital costs and to the effectiveness of market discipline. (Scanella \& Polizzi, 2019). 
During the last major international financial crisis, as a result of the bankruptcy or near bankruptcy of some US financial institutions, such as Lehman Brothers, AIG, Bears Stearns, attention turned to the accounting system, accusing the fair value for the crisis that has been introduced (Magnan, 2009). An environment of distrust of the financial information disclosed by companies was created, which contributed, in part, to the lack of confidence in the financial system (Financial Crisis Advisory Group, 2009).

When carrying out a diagnosis of the financial crisis, the Group of 20 (G20) (2009) concluded that:

- the weakness of disclosure played a significant role in the crisis;

- the information disclosed was not sufficient for many investors and other market participants;

- the information disclosed did not always make clear the type and magnitude of risks, including those associated with off-balance sheet exposures;

- the information disclosed on exposures to market and credit risk, particularly in relation to structured products, was deficient;

- the information was not always disclosed in a clear and understandable way.

Thus, accounting standardization bodies have been faced with the need to review regulations on financial instruments, seeking to reduce their complexity and increase the requirements for disclosing information. The International Accounting Stand ards Board (IASB) published International Financial Reporting Standard (IFRS) 9 - Financial Instruments, in July 2014, which aimed to replace the International Accounting Standard 39 - Financial Instruments: recognition and measurement. This new standard came into effect as of January 1, 2018, with the possibility of being adopted and tested in advance. This standard introduced new rules and principles, changing previous ones, such as the classification and measurement of assets, impairment, derivatives accounting and hedge accounting.

In fact, the main objective of IFRS 9 is to establish principles applicable to the financial reporting of financial assets and financial liabilities, which constitute relevant and useful information for users of financial statements, with a view to the possible assessment of amounts, moments of occurrence and degree of uncertainty of an entity's future cash flows ( IFRS 9, §1.1).

With regard to disclosures, "there is the introduction of new disclosure requirements related to credit risk and expected credit losses that will require a major 
disclosure effort" (Silva et al., 2017). On the other hand, according to the same authors, this disclosure should be carried out so that users can easily locate and understand it.

Consequently, IFRS 7 Financial Instruments - Disclosures was amended to accommodate the changes introduced by IFRS 9.

IFRS 7 aims to require entities to provide disclosures in their financial statements that allow users to assess ( $(1)$ : (a) the significance of financial instruments for the entity's financial position and performance; (b) the nature and extent of risks associated with financial instruments to which the entity is exposed during the reporting period and date, as well as how the entity manages those risks.

The two main categories of disclosures required by IFRS 7 are: information on the importance of financial instruments and information on the nature and extent of risks arising from financial instruments.

Derivative instruments are used to protect companies from the risks of price fluctuations, so the disclosure of these operations and their results revealed is of paramount importance to shareholders. Proper disclosure of these operations reduces information asymmetries between management and internal and external users of accounting reports (Malaquias \& Zambra, 2018).

On the other hand, corporate disclosure can be linked to the corporate governance structure, as it is the corporate governance structure itself that encourages a manager to adopt the best disclosure policies. According to Bidabad, Amirostovar, and Sherafati (2017), corporate governance, financial transparency, and disclosure of financial information are among the essential solutions to attract stakeholder's confidence in financial operations. The effects of corporate governance on reporting practices mitigate information asymmetries (Carmona, Fuentes, \& Ruiz, 2016) and improve the management function. Accurate information about risks, such as an external control mechanism that reduces agency costs, is essential for shareholders, analysts, and investors, allowing them to assess a company's risk profile, estimate its market value and make accurate investment decisions. (Elshandidy \& Neri, 2015).

As market participants are unable to observe management's actions and credibility directly, they often use corporate governance mechanisms to assess the quality of corporate risk disclosure since it is assumed that a good government of society is associated with efficient risk management (Elshandidy \& Neri, 2015).

According to agency theory, the characteristics of the board of directors, such as the size of the board, the presence of independent directors, and the dual functions of the 
CEO, can affect the quality and the level of financial information disclosed (Ali \& Abdelfettah, 2019). Also the auditor can play a key role in this process, exercising influence with its clients to properly disclose all the required information (Lemos, Serra, \& Barros, 2019).

Because of the above, the main objective of this paper is to study the influence of some characteristics associated with the board of directors and associated with the auditor on the level of disclosure on derivative instruments in Portuguese companies listed on Euronext Lisbon.

This study contributes to the literature on compliance with IFRS and may be useful for regulators in setting disclosure requirements for derivative instruments.

On the other hand, it contributes to the perception of the influence of certain characteristics associated with the board of directors and the auditor in the disclosure of derivative instruments. Thus, it may be useful in companies' decision making in defining the members of the board and the auditor.

To this end, an analysis was made of the reports and accounts of the referred companies reported in 2017. To measure the level of disclosure on derivative instruments, a disclosure index was built, based on the disclosure requirements contained in the International Financial Reporting Standard (IFRS) 7. Subsequently, using a multiple linear regression model, the specific characteristics associated with the corporate governance model that influenced the disclosure levels are identified.

This study has an innovative character, because, although there are several studies about derivative instruments' disclosure factors, there is no study, to the authors knowledge, that separately analyzes the influence of the board of directors and the auditor on derivatives' disclosure level. It also contributes to a better understanding of the relationship between disclosure on derivative instruments and the characteristics of the Board of Directors and the auditor in Portugal.

In addition to this introduction, this paper contains a section dedicated to reviewing the literature and defining the research hypotheses. The description of the research methodology adopted in the collection and treatment of data follows. Subsequently, the analysis and discussion of the results obtained are presented and, finally, the main conclusions, limitations of the study, and future research directions. 


\section{Literature review and hypotheses development}

Concerning the relationship between the characteristics of the board of directors and the characteristics of the auditor with the level of disclosure about financial instruments or financial derivative instruments, some studies proved the existence of an association between the level of the disclosure presented and the type of auditor (Lopes \& Rodrigues, 2007, Lemos, Rodrigues \& Rodriguez Ariza, 2009 and Lemos, 2011, and Tahat, Mardini \& Power, 2017), the size of the board (Tahat et al., 2017), the percentage of independent directors on the board of directors (Lemos, 2011) and the auditor's gender (Lemos et al., 2019).

Based on the premise of Elshandidy and Neri (2015), that the literature has shown that corporate governance mechanisms contribute to improving the disclosure of financial information, this study aims to determine whether the characteristics of the board of directors and the auditor influence derivative's disclosure level, based on the research hypotheses defined in the following points.

\section{Size of the board of directors}

Fathi (2013) and Martins (2014) state that the variable size of the board of directors has a positive impact on the quality of the financial information disclosed. In contrast, the empirical study by Miranda (2014) found a negative relationship between the number of members of the board of directors and the performance of companies. In the author's opinion, this relationship is because the number of members of the board of directors is too high, creating agency problems. Chantachaimongkol and Chen (2018) and Ali and Abdelfettah (2019) also found that there is a negative relationship between the size of the board and disclosure practices, indicating that smaller boards disclose more information. However, Oliveira (2016), in his empirical study, found that the variable size of the board of directors does not have a statistically significant relationship with the level of voluntary disclosure.

On the other hand, the results of the studies by Elshandidy and Neri (2015) Moumen, Othman, Hussainey (2016) and Agyei-Mensah (2017) show that higher boards of directors contribute to increased risk disclosure. Tahat et al. (2017) also found empirical evidence of a positive association between the percentage of independent members on the board and the level of financial instruments disclosure. 
Given the results presented, it is expected that the size of the board of directors will influence the level of disclosure about derivative instruments. Thus, the following research hypothesis was formulated:

H1: Derivative instruments' disclosure level is influenced by the number of members on the board of directors.

\section{Qualifications of the board of directors}

In the perspective of Ismail and Rahman (2011), a board of directors should be composed of people with good knowledge about accounting procedures so that useful disclosures are transmitted to stakeholders. Thus, if the board of directors has members with academic backgrounds in economics, management, accounting, and finance, the dissemination of information will be better. Consequently, these authors concluded that the qualification of the members of the board of directors positively influences the level of disclosure. Based on this conclusion, the following research hypothesis was formulated:

H2: Derivative instruments' disclosure level is influenced by the number of qualified members on the board of directors.

\section{Non-executive members and independence of the members of the board of directors}

The role of non-executive members in corporate governance has made a strong contribution to the fact that, at present, most corporate governance codes recommend the presence of a majority of independent members (Cunha, 2015). The model of the Corporate Governance Report contained in the Portuguese Securities Market Commission (CMVM), Regulation No. 4/2013 (point 18), recommends that the executive members be distinguished from the non-executive members and that, in relation to the non-executive members, those that can be considered independent. However, from the point of view of Ismail and Rahman (2011), the percentage of non-executive members on the board of directors is not a determining factor in the disclosure of information.

The Cadbury Report (1992) recommends that the majority of non-executive directors be independent. According to Barros, Boubakar, and Hamrouni (2013), the presence of independent directors on the board of directors is essential, given that they contribute, with their experience, to companies and protect the general interests of shareholders against potential opportunistic behavior. These members are expected to be neutral to all policies decided by the management bodies and, therefore, encourage us to 
disclose more transparent information to stakeholders (Istiningrum, 2019). In the wake of this thought, Lemos (2011) and Cunha and Rodrigues (2018) found evidence of a positive association between the number of independent members on the board of directors and the level of disclosure about derivative instruments and corporate governance, in Portuguese companies listed on the stock exchange, respectively.

Liu, Valenti and Chen (2016) also assessed that the independence of the members of the board of directors has a significant positive effect on the quality of the disclosure of financial information and Ali and Abdelfettah (2019) have also concluded that financial disclosure level increases with board independence. Agyei-Mensah (2017) also found empirical evidence of a positive association between the proportion of independent directors on the board and the level of IFRS 7 disclosure.

Tauringana and Chithambo (2020) also found a positive association between the level of compliance with IFRS 7 disclosure requirements and the proportion of nonexecutive directors.

In contrast, Ho and Wong (2011), Ismail and Rahman (2011), Fathi (2013), Miranda (2014) and Oliveira (2016), as well as Chantachaimongkol and Chen (2018) did not obtain any empirical evidence of the association between the percentage of independent members on the board of directors and the level of disclosure. Also, Lopes and Rodrigues (2007) and Lemos et al. (2009) did not obtain any empirical evidence of the association between the number of independent members on the board of directors and the disclosure of information on derivative instruments.

In turn, Martins (2014), in its empirical study, obtained a negative association between the level of voluntary disclosure and the number of independent members on the board of directors. Similarly Yamani, Hussainey and Albitar (2021) found evidence of a negative association between the level of disclosure on IFRS 7 and the independence of board members.

In view of the controversy of the results, we formulate the research hypotheses H3.1 and H3.2, as follows, which consider the influence of non-executive members and independent non-executive members on the level of disclosure presented, respectively:

H3.1: Derivative instruments' disclosure level is influenced by the number of independent members on the board of directors.

H3.2: Derivative instruments' disclosure level is influenced by the number of nonexecutive members on the board of directors. 


\section{Number of meetings of the board of directors}

According to Vafeas (1999), frequent meetings can be interpreted as a sign of active control, but they can also be the result of poor performance by the members of the board of directors. In turn, Miranda (2014) and Chantachaimongkol and Chen (2018) did not obtain any empirical evidence between the number of board meetings and the disclosure of information.

However, Fathi (2013) and Sanni, Aliu, and Olanrewaju (2020) evidenced that the variable participation of members in board meetings has a positive effect on the disclosure of information. Therefore, the following research hypothesis was formulated:

H4: Derivative instruments' disclosure level is influenced by the number of meetings of the board of directors.

\section{Type of audit firm}

Several studies have shown that the type of audit firm influences the audit process. Thus, the quality and level of information disclosed in reports and accounts are also influenced by the external auditor.

The empirical studies of Guerreiro (2006), Fathi (2013), Mokhtar and Mellett (2013), Campbell, Chen, Dhaliwal, Lu, and Steele (2014), Carmona et al. (2016), Zango, Kamardin, and Ishak (2016) and Fukukawa and Kim (2017), Habtoor, Ahmad, Mohamad, and Che Haat (2017), as well as Dey, Hossain, and Rezae (2018), revealed a positive association between the disclosure of risks and the type of audit firm. In other words, companies audited by the the largest auditing companies in the world (known as the Big 4, correspond to the companies Deloitte, PriceWhaterhouseCoopers, KPMG, Ernst\&Young) tend to disclose more information. Also, Lopes and Rodrigues (2007), Lemos et al. (2009), Lemos (2011) and Tahat et al. (2017) obtained a positive association between the type of external auditor and the disclosure of information on financial instruments or derivative instruments.

Conversely, in the investigation by Hassan et al. (2006/2007), Gonçalves (2013), Nunes (2014) and Lemos et al. (2019), it was concluded that the fact that the auditor belongs to one of the Big 4 does not influence the disclosure on derivative instruments. Because of the results obtained, the following research hypothesis was defined:

H5: Derivative instruments' disclosure level is influenced by the type of audit firm (Big 4 or not Big 4). 


\section{Gender of the external auditor}

According to Costa, Serra, and Gomes (2013), the gender of the external auditor influences the way information is collected, processed, and evaluated, with external auditors being more risk-averse (Breesch \& Branson, 2009). In the wake of this thought, the study by Ittonen, Vähämaa and Vähämaa (2013) found that behavioral differences between male and female auditors can have important implications for the quality of auditing and financial reporting.

The results of the study by Breesch and Branson (2009) indicate that female auditors found more potential distortions than male auditors. Therefore, Hardies, Breesch and Branson (2016) assert that the quality of the audit is greater when it is performed by female auditors. Likewise, Atmaja and Sukartha (2021) conclude that female auditors have better moral considerations in making audit judgments than male auditors and Feng (2020) concluded that female auditors are more likely to report internal control dificiencies and issue qualified audit opinions.

Pucheta-Martínez, Bel-Oms and Olcina-Sempere (2016) argue that the existence of female members on audit committees could increase the quality of the information disclosed and, consequently, increase investor confidence in the financial statements.

Lemos et al. (2019) obtained a positive association between the gender of the external auditor and the disclosure on the derivative instruments, showing that the level of disclosure is higher when the external auditor is male.

Given the results obtained, the following research hypothesis was formulated:

H6: Derivative instruments' disclosure level is influenced by the gender of the external auditor.

In addition to the characteristics associated with the board of directors and with he auditor, other business characteristics that influence the level of information disclosed by companies have been identified by several authors (Guerreiro, 2006; Hassan et al., 2006/2007; Lopes and Rodrigues, 2007; Lemos et al., 2009; Mapurunga, Ponte, Coelho \& Meneses, 2011; Lemos, 2011; Gonçalves, 2013; Oliveira 2016; Lemos et al., 2019). It was considered pertinent to study the influence of the entity's size and the entity's levels of profitability and leverage on derivative's disclosure level. 


\section{Size}

Guerreiro (2006), Hermalin and Weisbach (2012) Oliveira (2016) Ali and Abdelfettah (2019) and Tauringana and Chithambo (2020) obtained a positive association between the level of disclosure and the size of the company. The existence of a positive association between the level of disclosure on derivative instruments or financial instruments and the size of the company was also proven by Hassan et al. (2006/2007), Lopes and Rodrigues (2007), Lemos et al. (2009), Mapurunga et al. (2011), Lemos (2011), Gonçalves (2013), Tahat et al. (2017), Kota and Charumathi (2018) and Lemos et al. (2019).

Conversely, Nunes (2014) did not obtain any empirical evidence between the size of the company and the disclosure on derivative instruments.

Given the above, the following research hypothesis was formulated:

H7: Derivative instruments' disclosure level is influenced by the size of the company.

\section{Profitability}

According to Gallery, Cooper and Sweeting (2008), the most profitable companies tend to use external disclosure to guarantee their current position and avoid the devaluation of their shares. Hassan et al. (2006/2007) prove the existence of a positive association between the quality of the information disclosed on derivative instruments and the profitability of companies.

In contrast, Guerreiro (2006), Fathi (2013), and Oliveira (2016) did not obtain any empirical evidence between the profitability of companies and the disclosure of information. Also, Lemos et al. (2009), Mapurunga et al. (2011), Lemos (2011) and Nunes (2014) did not obtain any statistically significant evidence between the profitability of companies and the disclosure on derivative instruments.

Taking into account the results obtained by Hassan et al. (2006/2007), it is expected that the level of profitability of companies influences the level of disclosure about derivative instruments, resulting in the following research hypothesis:

H8: Derivative instruments' disclosure level is influenced by the companies' profitability. 


\section{Leverage}

Hassan et al. (2006/2007) and Lemos (2011) obtained empirical evidence of a positive association between the index of disclosure on derivative instruments and the level of leverage. Conversely, Guerreiro (2006), in his empirical study, obtained a negative association between the level of information disclosure and the level of leverage. Oliveira (2016) did not find any association between the disclosure of information and the level of leverage. Likewise, Lemos et al. (2009), Mapurunga et al. (2011) and Gonçalves (2013) found no association between the level of indebtedness and the disclosure on derivative instruments.

Despite the different results obtained by these authors, it is expected that corporates' leverage influences the level of disclosure on derivative instruments, forming the following research hypothesis.

H9: Derivative instruments' disclosure level is influenced by the companies' leverage.

Tables I and II present a summary of the formulated hypotheses and the estimated model

\section{METHODOLOGY}

\section{Sample selection and analysis period}

The main objective of this study is to analyze the influence of the corporate governance model on the level of disclosure on derivative instruments in companies listed on Euronext Lisbon. It is understood that listed companies are the ones that use derivative instruments more frequently and the level of reporting in this type of company is more demanding. The economic period of 2017 was considered, corresponding to the last one for which information was available. For the constitution of the final sample, the following criteria have been used:

a) The companies under analysis were included in the list that was removed from the Euronext Lisbon website, on November 9, 2018;

b) The Management Reports, Corporate Governance Reports, Audit Reports and Financial Statements of these companies would have to be available on the CMVM website; 
c) The companies considered were not Sports Limited Companies, since these entities have a different reporting period than the others.

The initial list of companies included 47 companies. Seven companies were excluded, since the Corporate Governance Reports and Management Reports did not contain enough information for the present study and three Sports Limited Companies, resulting in a sample of 37 companies.

\section{Collection and processing of data}

To achieve the defined objectives, a content analysis of the 2017 Annual Reports and Accounts of the companies that composed the sample was carried out. These Reports and Accounts were collected on the entities' webpages and / or on the CMVM's webpage. The documents that were analyzed refer to the Management Report, Corporate Governance Report, and the Financial Statements and respective annex and Audit Reports.

According to Severino (2017), content analysis is a methodology that treats and analyzes information from documents. Content analysis has its approach to analyzing data that largely derives from how the object of study and content is designed (Krippendorff, 2018).

The data have been collected based on the content analysis methodology, subsequently classifying the information collected in attributes and measure the level of disclosure, considering the disclosure index used by Lemos et al. (2009), Lemos (2011) and Lemos et al. (2019), which was built based on IFRS 7. The collected data were further processed and quantified using the Statistical Package for the Social Sciences (SPSS) statistical program, using multiple linear regression models for this purpose.

\section{Dependent variable}

The dependent variable used in this study consists of a disclosure index on derivative instruments, obtained from Lemos (2011), which contains all the disclosure

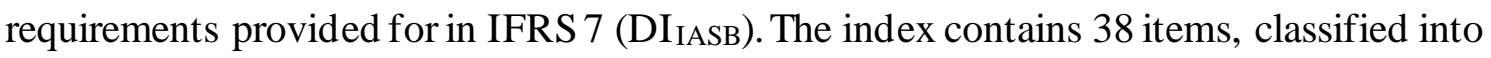
five main categories:

1. Accounting policies (6 items);

2. Specific information on risks (8 items);

3. Operations that do not qualify for hed ging purposes ( 2 items);

4. Hedging (18 items), divided into the following subcategories: 

a. General information (5 items);
b. Cash flow hedges ( 7 items);
c. Fair value hed ges ( 2 items);
d. Net investments in foreign entities hedges (4 items);
5. Fair value (4 items).

In the analysis of the reports and accounts of the companies included in the sample, we verified whether each of the items constituting the DI was disclosed or not, giving each of them a weighting of 0 or 1 , according to the following criteria:

$$
\begin{aligned}
& 0 \text { - the item was not disclosed; } \\
& \qquad 1 \text { - the item was disclosed. }
\end{aligned}
$$

Thus, the value of the index for each of the companies was obtained by the quotient between the total items disclosed by the company under analysis and the sum of the total of the items which make up the disclosure index, according to the following formula (see Figure I).

\begin{tabular}{|c|c|}
\hline & $\mathrm{DI}_{\mathrm{it}}=\sum_{j=i}^{e} e_{j} / \mathrm{e}$ \\
\hline $\begin{array}{l}\text { Wher } \\
\text { DIit } \\
e_{j} \\
\text { e }\end{array}$ & $\begin{array}{l}\text { Disclosure index of company } \mathrm{i} \text {, at time } \mathrm{t} \text {; } \\
\text { Disclosure element under analysis: } \\
\quad \text { Dichotomous variable, which assumes the value } 0 \text {, if element } \mathrm{j} \text { is not disclosed, and } \\
\text { value } 1 \text {, if element } \mathrm{j} \text { is disclosed } \\
\text { Maximum number of elements analyzed }\end{array}$ \\
\hline
\end{tabular}

Figure I. Disclosure index determination formula

The index value varies between 0 and 1 , and the higher the value of the DI, the higher the level of the disclosure presented.

In the analysis of the Reports and Accounts of the companies included in the sample, it is verified whether each of the items that constitute the IASB disclosure index (DIIASB) is or is not disclosed. A weighting of zero or one is assigned to each of them, depending on the following criteria: zero if the item is not disclosed and one if the item is disclosed.

In this way, the value of the index for each company under analysis is obtained through the quotient between total items disclosed and the sum of the total items that constitute the disclosure index. It should also be noted that the DI IASB is an unweighted index. That is, it is assumed that all items considered have the same level of importance for the various users of financial statements. 
On the other hand, it should be noted that the fact of not distinguishing between undisclosed items and non-applicable items may affect the results obtained. Many of the items not disclosed by the companies may be related to operations that were not carried out, and, for that reason, the fact of not disclosing does not mean non-compliance with the rules. However, it is impossible to control (due to the lack of information presented) if the non-disclosure of a particular item is due to the lack of compliance with the regulations or its non-application, so it was chosen to be classified as not disclosed.

\section{Independent variables}

The independent variables resulted from the research hypotheses previously formulated and were determined for the period of analysis. Table I presents a summary of the independent variables used, with an indication of how to assess each one and the underlying research hypotheses.

Table I: Independent variables

\begin{tabular}{|c|c|c|}
\hline Variables & Determination form & Hypothesis \\
\hline Board size (BSize) & Number of members on the board of directors & H1 \\
\hline $\begin{array}{l}\text { Qualifications of board } \\
\text { members }(\mathrm{QBM})\end{array}$ & $\begin{array}{l}\text { Percentage of board members with a degree in } \\
\text { Economics / Management / Auditing / Finance }\end{array}$ & $\mathrm{H} 2$ \\
\hline $\begin{array}{l}\text { Independence of the members of } \\
\text { the board of directors (IndBM) }\end{array}$ & $\begin{array}{c}\text { Percentage of independent members on the board of } \\
\text { directors }\end{array}$ & H3.1 \\
\hline $\begin{array}{l}\text { Non-executive members of the } \\
\text { board of directors (NonEx) }\end{array}$ & $\begin{array}{l}\text { Percentage of non-executive members on the board } \\
\text { of directors }\end{array}$ & H3.2 \\
\hline $\begin{array}{l}\text { Board of directors' meetings } \\
\text { (BMeet) }\end{array}$ & Number of meetings held on the board of directors & $\mathrm{H} 4$ \\
\hline Big 4 & $\begin{array}{l}\text { Dummy variable: } \\
0 \text { - if the audit firm does not belong to the Big } 4 \\
1 \text { - if the audit firm belongs to the Big } 4\end{array}$ & H5 \\
\hline $\begin{array}{l}\text { External auditor gender } \\
\text { (Gender) }\end{array}$ & $\begin{array}{l}\text { Dummy variable: } \\
0 \text { - if the externalauditor is female } \\
1 \text { - if the externalauditor is male }\end{array}$ & H6 \\
\hline Size & Totalasset log & H7 \\
\hline Profitability (ROA) & ROA - return on assets & $\mathrm{H} 8$ \\
\hline Leverage (Lev) & liabilities/a ssets $\mathrm{x} 100$ & H9 \\
\hline
\end{tabular}




\section{Regression model}

To identify the determinants of the level of disclosure about derivative instruments a multiple linear regression model was developed in line with the hypotheses formulated. The estimated model is expressed in Table II below:

Table II: Regression model

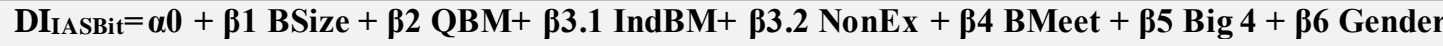
$+\beta 7$ Size $+\beta 8$ ROA $+\beta 9$ Lev $+\varepsilon_{\text {it }}$

DI IASBit: disclosure index value for company iat time t;

BSize: number of members on the board of directors;

QBM: number of members licensed in the area of management/economics / finance / auditing on the board of directors;

IndBM: number of independent members on the board of directors;

BMeet: number of meetings held on the board of directors;

NonEx: number of non-executive members on the board of directors;

Big 4: if the auditor belongs to a Big 4;

Gender: gender of the auditor;

Size: company size;

ROA: return on assets;

Lev: leverage.

\section{Empirical results and discussions}

\section{Sample Characterization}

The sample used in this study is made up of companies listed on Euronext Lisbon on December 31, 2017, excluding Sports Corporations and companies that did not disclose information regarding the Corporate Governance Report and the Management Report. Thus, the sample consists of 37 companies. Table III shows the characterization of the companies that make up the sample, taking into account the quantitative independent variables previously presented.

Table III: Characterization of the sample according to the quantitative independent variables

\begin{tabular}{|l|c|c|c|c|}
\hline \multicolumn{1}{|c|}{ Variables } & Mean & $\begin{array}{c}\text { Standard } \\
\text { deviation }\end{array}$ & Minimum & Maximum \\
\hline Number of members of the board of directors & 9.22 & 4.70 & 3 & 19 \\
\hline Qualifications of members of the board of directors (\%) & $43 \%$ & $18 \%$ & $0 \%$ & $79 \%$ \\
\hline $\begin{array}{l}\text { Number of independent members on the board of } \\
\text { directors (\%) }\end{array}$ & $27 \%$ & $23 \%$ & $0 \%$ & $67 \%$ \\
\hline Number of board meetings & 12.51 & 8.95 & 1 & 47 \\
\hline Non-executive members of the board of directors & 0.49 & 0.23 & 0 & 18 \\
\hline Size & 8.86 & 0.97 & 6.36 & 10.86 \\
\hline ROA (\%) & $-9.21 \%$ & $54.75 \%$ & $-300 \%$ & $18 \%$ \\
\hline Leverage (\%) & $65.41 \%$ & $34.77 \%$ & $3.00 \%$ & $214 \%$ \\
\hline
\end{tabular}


It can be seen in Table III, that the number of members of the board of directors of companies in sample varies between 19 and three members, with an average of approximately 9 members.

Regarding the qualifications of the members, it is possible to observe that, of the 37 companies under analysis, the average number of members with a degree in Economics / Management / Accounting / Finance / Auditing is 43 per cent, with a minimum of zero per cent and a maximum of 79 per cent.

The average number of independent members of the board is 27 per cent, with a minimum of zero per cent and a maximum of 67 per cent. This means that there are companies where the members of the board of directors are all dependent. Although the presence of independent directors on the board is considered necessary, as they contribute with their experience to the companies and protect the general interests of shareholders against potential opportunistic behavior.

The average number of meetings held on the board is approximately 13, a minimum of one meeting, and a maximum of 47 meetings.

Regarding the number of non-executive members, it can be attested that there are companies that do not have non-executive members on the board of directors. Conversely, some companies have up to 18 non-executive members. However, the average does not reach 1, indicating that the majority of the companies analyzed do not have non-executive members on the board of directors.

As for the size of the company, it is possible to verify that the average is 8.86 , the maximum being 10.86, and the minimum 6.36 .

Concerning return on assets (ROA), it appears that the average is -9.21 per cent, a maximum of $18 \%$, and a minimum of -300 per cent.

Finally, leverage averages 65.41 per cent, with a maximum of 214 per cent and a minimum of 3 per cent.

Table IV shows the characterization of the companies that make up the sample, taking into account the dichotomous independent variables.

Table IV: Characterization of the sample according to dichotomous variables

\begin{tabular}{|c|c|c|c|}
\hline \multirow{2}{*}{ Big4 } & & N & \% \\
\hline \multirow{3}{*}{} & No & 7 & 18.9 \\
\hline \multirow{2}{*}{ Gender } & Yes & 30 & 81.1 \\
\cline { 2 - 4 } & Total & 37 & 100 \\
\hline \multirow{2}{*}{} & Female & 4 & 89.2 \\
\hline
\end{tabular}


By analyzing Table IV, it appears that about 81per cent of the companies use one of the Big4 companies to issue the external audit report. Concerning the auditor's gender, it is possible to observe that there are only four female auditors, the remaining 33 being male.

As it is possible to analyze through the available data in table III and table IV, the sample presents extremely dispersed values in relation to all the considered variables, indicating that the sample is composed of companies with very different characteristics among them. This dispersion of data may justify some of the results obtained.

\section{Descriptive analysis of results}

About DIIASB and the respective disclosure sub-indices, the mean values, standard deviation, minimum and maximum values were calculated, as shown in Table V.

Table V: Descriptive statistics of disclosure indexes

\begin{tabular}{|l|c|c|c|c|}
\hline \multicolumn{1}{|c|}{ Indexes } & Mean & $\begin{array}{c}\text { Standard } \\
\text { deviation }\end{array}$ & Minimum & Maximum \\
\hline DI & 0.54 & 0.30 & 0.00 & 0.87 \\
\hline DI 1 - Accounting policies & 0.74 & 0.40 & 0.00 & 1.00 \\
\hline DI 2 - Specific risk information & 0.57 & 0.29 & 0.00 & 1.00 \\
\hline DI 3 - Operations that do not qualify as hedging & 0.51 & 0.46 & 0.00 & 1.00 \\
\hline DI 4 - Hedging - general information & 0.70 & 0.45 & 0.00 & 1.00 \\
\hline DI 5 - Cash flow hedges & 0.38 & 0.27 & 0.00 & 0.86 \\
\hline DI 6 - Fair value hedge & 0.61 & 0.43 & 0.00 & 1.00 \\
\hline DI 7 - Net investments in foreign entities hedges & 0.22 & 0.32 & 0.00 & 0.75 \\
\hline DI 8 - Fair value & 0.53 & 0.36 & 0.00 & 1.00 \\
\hline
\end{tabular}

From the analysis to Table $\mathrm{V}$, it appears that none of the companies presents all the

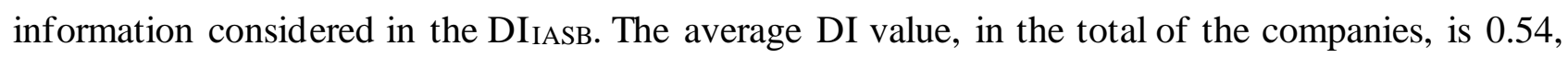
with a minimum disclosure value of zero and a maximum disclosure value of 0.87 .

For each category of information, a disclosure sub-index was created, ranging from DI 1 to DI 8. For each sub-index, the mean values, standard deviation, minimums, and maximums were also calculated.

The sub-index with the highest average value is DI 1, with an average disclosure of 0.74 , which means that companies are concerned with providing information related to the accounting policies adopted in the treatment of transactions with derivative instruments. Then comes DI 4, with an average of 0.70 , indicating that companies are also concerned with providing general information regarding hedging operations with derivative instruments.

The sub-index with the lowest average values is DI 7, with a disclosure average of 0.22 , indicating that companies are not concerned with providing information regarding net investments in 
foreign entities hedges. DI 5 presents an average of 0.38 , meaning that companies also do not give importance to the provision of information regarding cash flow hedges.

Regarding disclosure sub-indices 1, 2, 3, 4, 6, and 8, some companies disclose all items considered in these categories (maximum value $=$ one), although, for all sub-indexes considered, the minimum value is equal to zero.

Given the results presented, it is possible to verify that the disclosure levels are low, leading us to believe that companies listed on Euronext Lisbon do not comply with the disclosure requirements contained in the current accounting standards. However, compared to the study of Lemos et al. (2019), it is possible to verify that there is a positive evolution since the DI of this study is on average 0.54 and that of Lemos et al. (2019) is 0.49. Thus, it is possible to confirm that in 2017 companies released a greater amount of information compared to 2016.

This result is also consistent to the result obtained by Tahat et al. (2017), who also obtained a disclosure level about financial instruments of 52\%, in Jordanian listed companies.

\section{Multivariate Analysis}

To verify the relationship between independent variables and the dependent variable it was developed a multiple linear regression model, according to the formulated hypotheses, which is presented in Table VI, Table VII, and Table VIII, below.

Table VI: Model summary

\begin{tabular}{|c|c|c|c|c|c|c|c|c|c|c|}
\hline \multirow[b]{2}{*}{ Model } & \multirow[b]{2}{*}{$\mathbf{R}$} & \multirow[b]{2}{*}{$\begin{array}{c}\mathbf{R} \\
\text { Square }\end{array}$} & \multirow[b]{2}{*}{$\begin{array}{c}\text { Adjusted } \\
\text { R } \\
\text { Square }\end{array}$} & \multirow{2}{*}{$\begin{array}{c}\text { Std. } \\
\text { Error of } \\
\text { the } \\
\text { Estimate }\end{array}$} & \multicolumn{5}{|c|}{ Change Statistics } & \multirow[b]{2}{*}{$\begin{array}{l}\text { Durbin- } \\
\text { Watson }\end{array}$} \\
\hline & & & & & $\begin{array}{c}\text { R } \\
\text { Square } \\
\text { Change }\end{array}$ & $\begin{array}{c}\text { F } \\
\text { Change }\end{array}$ & df1 & df2 & $\begin{array}{c}\text { Sig. F } \\
\text { Change }\end{array}$ & \\
\hline 1 & .752 & .566 & .399 & .23345 & .566 & 3.393 & 10 & 26 & .006 & 2.144 \\
\hline
\end{tabular}

\begin{tabular}{|c|c|c|c|c|c|c|}
\hline \multicolumn{7}{|c|}{ Table VII: Anova } \\
\hline \multicolumn{2}{|l|}{ Model } & $\begin{array}{l}\text { Sum of } \\
\text { Squares }\end{array}$ & df & $\begin{array}{l}\text { Mean } \\
\text { Square }\end{array}$ & $\mathbf{F}$ & Sig. \\
\hline \multirow[t]{3}{*}{1} & Regression & 1.849 & 10 & .185 & 3.393 & .006 \\
\hline & Residual & 1.417 & 26 & .054 & & \\
\hline & Total & 3.266 & 36 & & & \\
\hline
\end{tabular}


Table VIII: Coefficients

\begin{tabular}{|c|c|c|c|c|c|c|}
\hline & \multirow[t]{2}{*}{ Model } & \multicolumn{2}{|c|}{$\begin{array}{l}\text { Unstandardized } \\
\text { Coefficients }\end{array}$} & \multirow{2}{*}{$\begin{array}{c}\text { Standardized } \\
\text { Coefficients } \\
\text { Beta }\end{array}$} & \multirow[t]{2}{*}{$\mathbf{t}$} & \multirow[t]{2}{*}{ Sig. } \\
\hline & & B & Std. Error & & & \\
\hline \multirow{11}{*}{1} & (Constant) & -1.761 & 0.572 & & -3.079 & 0,005 \\
\hline & BSize & -0.008 & 0.014 & -0.118 & -0.532 & 0.599 \\
\hline & QBM & -0.04 & 0.24 & -0.024 & -0.166 & 0.87 \\
\hline & indBM & -0.643 & 0.267 & -0.488 & -2.404 & 0.024 \\
\hline & BMeet & -0.003 & 0.005 & -0.101 & -0.628 & 0.535 \\
\hline & NonEX & 0.139 & 0.282 & 0.108 & 0.493 & 0.626 \\
\hline & Big4 & -0.057 & 0.153 & -0.074 & -0.368 & 0.715 \\
\hline & Gender & 0.389 & 0.151 & 0.406 & 2.58 & 0.016 \\
\hline & Size & 0.238 & 0.077 & 0.767 & 3.084 & 0.005 \\
\hline & ROA & -0.001 & 0.001 & -0.234 & -1.344 & 0.191 \\
\hline & Lev & 0.002 & 0.001 & 0.203 & 1.294 & 0.207 \\
\hline
\end{tabular}

As can be seen from the analysis in table VIII, for a significance level of 5 per cent, the variables independence of the members of the board of directors, gender of the auditor, and size of the company are presented as determining factors of the derivative instruments' level of disclosure.

As such, it can be said that the number of independent members on the board of directors influences the level of disclosure, validating hypothesis 3.1. In this study, it is possible to observe that the smaller the number of independent members on the board, the higher the level of disclosure on derivative instruments. This result is consistent to the result obtained by Yamani et al. (2021), who also concluded that there was a negative association between the level of disclosure on IFRS 7 and the independence of board members. Lemos (2011) Agyei-Mensah (2017) and Tahat et al. (2017)obtained positive empirical evidence of the association between the disclosure index and the number of independent members on the board of directors. However, the results obtained in our study are contrary to the results obtained by these authors, who had concluded that the higher the number of independent members on the board, the higher the level of disclosure about derivative instruments, IFRS 7, and financial instruments, respectively. This result can also be explained by the dispersion of data that we verified in table III, since it is possible to conclude that there is a large number of companies with a reduced number of independent members on the board of directors. Nevertheless, Ho and Wong (2011), Ismail and Rahman (2011), Lopes and Rodrigues (2007), Lemos et al. (2009), Fathi (2013), Miranda (2014), and Oliveira (2016) did not obtain any association with the variable independence of the members of the board of directors. 
It can also be concluded by the influence of the external auditor's gender on the level of disclosure. The results show that, if the external auditor is male, the level of disclosure will be higher, validating hypothesis 6 . This result is supported by Lemos et al. (2019), who also obtained empirical evidence of a positive association between derivatives' level of disclosure and the auditor's gender. Still, it is contrary to the result of Miranda (2014), who did not obtain any association with the auditor's gender. It was expected that female external auditors would exert greater influence in the disclosure of derivative instruments, considering the results of Breesch and Branson (2009), who concluded for the higher quality of the audit when the auditor is female. Although, this result may also be justified by the fact that there are only 4 companies whose external auditors are female, indicating that most companies in the sample use male auditors.

According to the report and accounts for 2020 of the Statutory Auditors Order (Ordem dos Revisores Oficiais de Contas, OROC, in Portuguese) (OROC, 2020), only 30\% of Statutory Auditors registered in the Order are female, which may also justify the result obtained, since there is a reduced proportion of female professionals compared to male professionals.

The size of the company also influences the level of disclosure, validating hypothesis 7 , and revealing that the larger the size of the company, the higher the level of disclosure about derivative instruments. Also, Hassan et al. (2006/2007), Guerreiro (2006), Lopes and Rodrigues (2007), Lemos et al. (2009), Mapurunga et al. (2011), Lemos (2011), Gonçalves (2013), Oliveira (2016), Tahat et al. (2017), Malaquias and Zambra (2018) and Lemos et al. (2019) obtained empirical evidence of the association between the disclosure index and the size of the company. In contrast, Miranda (2014), and Nunes (2014), did not obtain any association between the size of the company and the disclosure index on derivative instruments.

Regarding the remaining variables, it is not possible to prove the existence of an association with the disclosure index. Therefore, like Oliveira (2016), that has not found any association between the size of the board and the level disclosure, the research hypothesis 1 was not validated. However, Fathi (2013), Martins (2014) Miranda (2014) found an association between the size of the board of directors and the disclosure index on derivative instruments

About the qualifications of the members of the board of directors, the results corroborated those of the study by Ismail and Rahman (2011), revealing the lack of association between qualifications of the members and disclosure index on derivative instruments, leading the rejection of hypothesis 2 . 
Like Miranda (2014), there was no association with the variable meetings of the board of directors and the disclosure index, and hypothesis 4 was not validated. However, these results are contrary to those obtained by Fathi (2013).

It was also not possible to validate hypothesis 3.2, showing, like Ismail and Rahman (2011), that there is no association between the number of non-executive members of the board and the disclosure index.

Unlike the studies by Hassan et al. (2006/2007), Gonçalves (2013), Nunes (2014) Tahat et al. (2017), and Lemos et al. (2019), no association was found between the variable type of audit firm and level of disclosure, so hypothesis 5 was also not validated.

Regarding the variable profitability (ROA), the results obtained are consistent with those of the studies by Guerreiro (2006), Lemos et al. (2009), Mapurunga et al. (2011), Fathi (2013), Nunes (2014) and Oliveira (2016). They did not show any association between profitability and the level of disclosure.

Corroborating the studies by Lemos et al. (2009), Mapurunga et al. (2011), Gonçalves (2013) and Oliveira (2016), this study showed the absence of an association between the level of leverage and the level of disclosure on derivative instruments, thus hypothesis 9 not being valid. Contrary to what happened in the investigations of Hassan et al. (2006/2007) and Lemos (2011).

Table IX below summarizes the hypothesis validation.

Table IX: Hipothesis validation

\begin{tabular}{|c|l|c|}
\hline $\begin{array}{c}\text { Hypothesis } \\
\text { Number }\end{array}$ & \multicolumn{1}{|c|}{ Hypothesis formulated } & $\begin{array}{c}\text { Hypohesis } \\
\text { Validation }\end{array}$ \\
\hline H1 & $\begin{array}{l}\text { Derivative instruments' disclosure level is influenced by the number of members on } \\
\text { the board of directors. }\end{array}$ & Not validated \\
\hline H2 & $\begin{array}{l}\text { Derivative instruments' disclosure level is influenced by the number of qualified } \\
\text { members on the board of directors. }\end{array}$ & Not validated \\
\hline H3.1 & $\begin{array}{l}\text { Derivative instruments' disclosure level is influenced by the number of independent } \\
\text { members on the board of directors. }\end{array}$ & Validated \\
\hline H3.2 & $\begin{array}{l}\text { Derivative instruments' disclosure level is influenced by the number of non- } \\
\text { executive members on the board of directors. }\end{array}$ & Not validated \\
\hline H4 & $\begin{array}{l}\text { Derivative instruments' disclosure level is influenced by the number of meetings of } \\
\text { the board of directors. }\end{array}$ & Not validated \\
\hline H5 & $\begin{array}{l}\text { Derivative instruments' disclosure level is influenced by the type of audit firm (Big } \\
\text { 4 or not Big 4). }\end{array}$ & Not validated \\
\hline H6 & $\begin{array}{l}\text { Derivative instruments' disclosure level is influenced by the gender of the ex ternal } \\
\text { auditor. }\end{array}$ & Validated \\
\hline H7 & Derivative instruments' disclosure level is influenced by the size of the company. & Validated \\
\hline H8 & $\begin{array}{l}\text { Derivative instruments' disclosure level is influenced by the companies' } \\
\text { profitability. }\end{array}$ & Not validated \\
\hline H9 & Derivative instruments' disclosure level is influenced by the companies' leverage. & Not validated \\
\hline
\end{tabular}




\section{CONCLUSIONS}

This study aimed to analyze the association between the board of directors and the auditor with the level of disclosure on derivative instruments, based on a sample of 37 Portuguese companies listed on Euronext Lisbon, in 2017. The research was carried out through the content analysis of Reports and Accounts of the companies and the use of an index to measure the disclosure level on derivative instruments.

To identify the determinants of disclosure and evaluate the influence of the board and the auditor a multiple linear regression model was developed, considering the variables defined in the previously formulated research hypotheses.

The results obtained show that the entities with the lowest number of independent members on the board of directors and whose external auditor is of the male gender present higher levels of disclosure on derivative instruments.

Regarding the control variables, the results reveal that the size of the entity also influences the derivatives' level of disclosure.

As it was found, none of the companies analyzed presents all the information considered in the DI IASB, with the maximum disclosure value being 87 per cent and the average DI IASB value being 54 per cent. In this context, companies provide more information related to the accounting policies adopted in the treatment of derivative instruments and hedging operations with derivative instruments, relegating information about the hed ging of net investments in foreign entities and cash flow hedges.

Given the results presented, it is possible to verify that the disclosure levels are low, concluding that the companies listed on Euronext Lisbon do not comply with all the disclosure requirements contained in the accounting standards. This compliance should occur, mainly to improve the decision-making process of stakeholders and increase the credibility and transparency of financial information.

As such, the authors believe it is important to encourage companies to increase the disclosure levels presented, in order to respond to the information needs of the different users of financial statements and to ensure compliance with the requirements of IFRS 7. The auditor can play a key role in this process, exercising influence with its clients to properly disclose all the required information.

For future investigation, it is suggested to expand the sample, to include entities not listed on a regulated market, and to include entities subject to the Portuguese 
Accounting Standardization System. Also, it is suggested to extend the period of analysis, which would allow concluding the evolution in the level of disclosure. The study of information disclosed for 2018 and subsequent years would also allow conclusions to be drawn about the impact of the adoption of IFRS 9 on derivative instruments' disclosure.

\section{REFERENCES}

Agyei-Mensah, B. K., (2017). The relashionship between corporate governance mechanisms and IFRS 7 compliance: evidence from an emerging market. Corporate Governance: The International Journal of Business in Society, 17(3), doi: 10.1108/CG-06-2016-0129.

Ali, A., \& Abdelfettah, B. (2019). Financial disclosure information board of directors , and firms characteristics among French CAC 40 listed firms. Journal of the Knowledge Economy, DOI:10.1007/s13132-017-0503-z

Atmaja, I. W., \& Sukartha, I. M. (2021). The influence of self efficacy, professional, sketicism, and gender o auditors on audit judgement. American Journal of Hummanities and Social Sciences Research, 5(1), 643-650.

Barros, C., Boubakar, S., \& Hamrouni, A. (2013). Corporate governance and voluntary disclosure in France. The Journal of Applied Business Research, 29(2), 561-578.

Bidabad, B., Amirostovar, A., \& Sherafati, M. (2017). Financial transparency, corporate governance and information disclosure of the entrepreneur's corporation in Rastin banking. International Journal of Law and Management, 59(5), 636-651.

Breesch, D., \& Branson, J. (2009). The effects of auditor gender on audit quality. The IUP Journal of Accounting Research and Audit Practices, 8(3-4), 78-107.

Campbell, J., Chen, H., Dhaliwal, D., Lu, H., \& Steele, L. (2014). The information content of mandatory risk factor disclosures in corporate filings. Review of Accounting Studies, 19(1), 396-455.

Carmona, P., Fuentes, C. D., \& Ruiz, C. (2016). Risk disclosure analysis in the corporate governance annual report using fuzzy-set qualitative comparative analysis. Revista de Administração de Empresas, 56(3), 342-352.

Chantachaimongkol, N., \& Chen, S. (2018). The effects of board compositions and audit committee characteristics on information disclosure practices: a case of Singapore. Asian Journal of Finance and Accounting, 10(1), 407-427.

Costa, R., Serra, S., \& Gomes, P. (2013). Fatores determinantes da opinião do auditor: estudo empírico das empresas portuguesas. Paper presented at XIV Congresso Internacional de Contabilidade e Auditoria, 10 e 11 de outubro, ISCAL, Lisboa. 
Cunha, V. (2015). Divulgação de Informação sobre o Governo das Sociedades em Portugal: Extensão e Determinantes. Doctoral dissertation, Universidade do Minho.

Cunha, V., \& Rodrigues, L. (2018). Determinants of structure of corporate governance disclosure in Portugal. Review of Business Management, 20(3), 338-360.

Dey, R., Hossain, S., \& Rezae, Z. (2018). Financial risk disclosure and financial attributes among publicly traded manufacturing companies: evidence from Bangladesh. Journal of Risk and Financial Management, 11(50), 1-16.

Elshandidy, T., \& Neri, L. (2015). Corporate governance, risk disclosure practices, and market liquidity: comparative evidence from the UK and Italy. Corporate Governance: An International Review, 23(4), 331-356.

Fathi, J. (2013). The determinants of the quality of financial information disclosed by French listed companies. Mediterranean Journal of Social Sciences, 4(2), 319319.

Feng, N. C. (2020). Individual auditor characteristics and audit quality: evidence from nonprofits in the US. Journal of Public Budgeting, Accounting \& Financial Management, 32(4), 551-575. https://doi.org/10.1108/JPBAFM-10-2019-0157

Financial Crisis Advisory Group (2009). Report of the Financial Crisis Advisory Group, Julho;

Fukukawa, H., \& Kim, H. (2017). Effects of audit partners on clients' business risk disclosure. Accounting and Business Research, 47(7), 780-809.

G20 Working Group (2009). Enhancing sound regulation and strengthening transparency: final report. Março. Documento disponível em http://www.g20.org;

Gallery, G., Cooper, E., \& Sweeting, J. (2008). Corporate disclosure quality: lessons from Australian companies on the impact of adopting International Financial Reporting Standards. Australian Accounting Review, 18(3), 257-273.

Gonçalves, M. (2013). Contabilidade de instrumentos financeiros derivados: Estudo empírico dos determinantes do nível de divulgação na Euronext Lisbon para o ano de 2010. Master dissertation, Instituto Universitário de Lisboa.

Guerreiro, M. (2006). Impacto da adopção das International Financial Reporting Standards: factores explicativos do nível de informação divulgada pelas empresas portuguesas cotadas. Contabilidade e Gestão, 3, 7-32.

Habtoor, O., Ahmad, N., Mohamad, N., \& Che Haat, M. (2017). Linking corporate risk disclosure practices with firm-specific characteristics in Saudi Arabia. Gadjah Mada International Journal of Business, 19(3), 247. 
Hassan, S., Percy, M., \& Stewart, J. (2006/2007). The transparency of derivative disclosures by Australian firms in the extractive industry. Corporate, Ownership and Control, 4(2), 257-270.

Hermalin, B., \& Weisbach, M. S. (2012). Information disclosure and corporate governance. The Journal of Finance, 67(1),195-233.

Ho, S., \& Wong, K. (2001). A study of the relationship between corporate governance structures and the extent of voluntary disclosure. Journal of International Accounting, Auditing and Taxation, 10(2), 139-156.

International Accounting Standards Board, IASB. (2006). International Financial Reporting Standard 7 - Financial Instruments: Disclosures. Retrieved from https://eur-lex.europa.eu/legalcontent/PT/TXT/HTML/?uri=CELEX:02008R112620200101\&qid=15790218170 $10 \&$ from $=\mathrm{EN}$

International Accounting Standards Board, IASB. (2012). International Financial Reporting Standard 9 - Financial Instruments. Retrieved from https://eurlex.europa.eu/legalcontent/PT/TXT/HTML/?uri=CELEX:02008R112620200101\&qid=15790218170 $10 \&$ from $=\mathrm{EN}$

Ismail, R., \& Rahman, A. (2011). Institutional investors and board of directors' monitoring role on risk management disclosure level in Malaysia. The IUP Journal of Corporate Governance, 10(2)37-61.

Istiningrum, A. (2019). Coporate governance, IFRS disclosure, and stock liquidity in Indonesian mining companies. Advances in Economics, Business and Management Research, 120, 271-278.

Ittonen, K., Vähämaa, E., \& Vähämaa, S. (2013). Female auditors and accruals quality. Accounting Horizons, 27(2), 205-228.

Kota, H. B., \& Charumathi, B. (2018). Determinantes of financial derivative disclosures in an emerging economy: A Stewardship theory perspective. Australasian Accounting Business \& Finance Journal, 12(3), 62-86.

Krippendorff, K. (2018). Content analysis: an introduction to its methodology (Fourth Edition), Sage publications, London.

Lemos, K. (2011). Contabilidade de instrumentos derivados. Estudo da informação divulgada pelas empresas portuguesas. Doctoral dissertation. Facultad de Ciencias Económicas y Empresariales, Universidad de Santiago de Compostela.

Lemos, K., Rodrigues, L., \& Rodríguez Ariza, L. (2009). Determinantes do nível de divulgação de informação sobre instrumentos derivados. Evidência empírica no mercado de capitais português. Tékhne - Revista de Estudos Politécnicos, VII(12), $145-175$. 
Lemos, K., Serra, S., \& Barros, A. (2019). The auditor as a determining factoron derivate financial instruments disclosures. In Marques, R., Santos, C., and Inácio, H. (Ed.), Organization Auditing and Assurance in the Digital Age., IGI GLOBAL, 70-93.

Liu, Y., Valenti, A., \& Chen, Y. J. (2016). Corporate governance and information transparency in Taiwan's public firms: The moderating effect of family ownership. Journal of Management and Organization, 22(5), 662-679.

Lopes, T., \& Rodrigues, L. (2007). Accounting for financial instruments: an analysis of the determinants of disclosure in the Portuguese stock exchange. The International Journal of Accounting, 42, 25-56.

Magnan, M. L. (2009). Fair value accounting and the financial crisis: messenger or contributor?. Accounting Perspective, 8 (3), 189-213;

Malaquias, R. F., \& Zambra, P. (2018). Disclosure of financial instruments: practices and challenges of latin American firms from the mining industry. Research in International Business and Finance, 45, 158-167.

Mapurunga, P., Ponte, V., Coelho, A., \& Meneses, A. (2011). Determinantes do nível de disclosure de instrumentos financeiros derivativos em firmas brasileiras. Revista Contabilidade \& Finanças, 22(5), 263-278.

Martins, R. (2014). O governo das sociedades e o relato voluntário das entidades do PSI20. Master dissertation, Universidade do Minho.

Miranda, C. (2014). A influência do governo das sociedades na qualidade dos resultados. Master dissertation, Universid ade do Porto.

Mokhtar, E., \& Mellett, H. (2013). Competition, corporate governance, ownership structure and risk reporting. Managerial Auditing Journal, 28(9), 838-865.

Moumen, N., Othman, H., \& Hussainey, K. (2016). Board structure and the informativeness of risk disclosure: evidence from MENA emerging markets. Advances in Accounting incorporating Advances in International Accounting, 35, 82-97.

Nunes, S. (2014). A divulgação sobre Instrumentos Derivados: evidencia empírica do setor da indústria português. Master dissertation, Instituto Superior de Contabilidade e Administração de Lisboa.

Oliveira, G. (2016). Estudo da relação entre o governo das sociedades e a divulgação voluntária pelas empresas do PSI-20. Master dissertation, Universidade do Minho.

Ordem dos Revisores Oficiais de Contas, OROC (2020). Relatório de Gestão e Contas, document availabe at www.oroc.pt.

Pucheta-Martínez, M. C., Bel-Oms, I., \& Olcina -Sempere, G. (2016). Corporate governance, female directors and quality of financial information. Business Ethics: A European Review, 25(4), 363-385. 
Ratna, T., \& Anisykurlillah, I. (2020). The Effect of Experience, Independence, and Gender on Auditor Professional Scepticism with Professional Ethics as Moderating. Accounting Analysis Journal, 9(2), 138-145. https://doi.org/10.15294/aaj.v9i2.25629

Sanni, M., Aliu, I., \& Olanrewaju, Y. (2020). Board characteristics and International Financial Reporting Standards (IFRS) compliance among Nigerian listed companies: mixed method approach. Global Journal of Accounting, 6(1), 24-40.

Scannella, E., \& Polizzi, S. (2019). Do large European Banks differ in their derivative disclosure practices? A cross-country empirical study. The Joural of Corporate Accounting \& Finance, 14-35, DOI 10.1002jcaf.

Severino, A. (2017). Metodologia do Trabalho Científico (24ํ Edição), Cortez, São Paulo:

Silva, E., Mota, C., \& Pereira, A. (2017). IFRS 9 - Instrumentos Financeiros : abordagem e impactos previsíveis do novo modelo de mensuração e registo de perdas de crédito. $\quad$ Retrieved from https://www.occ.pt/pt/dtrab/trabalhos/listacc/trabalhoscc.php

Tahat, Y., Mardini, G., \& Power, D. (2017). Factors affecting financial instruments disclosure in emerging economies. Afro-Asian Journal of Finance and Accounting, 7(3), 255-280, DOI: 10.1504/AAJFA.2017.10006170.

Tauringana, V., \& Chithambo, L. W. (2020). Determinants of risk disclosure compliance in Malawi: a mixed-method approach. Journal of Accounting in Emerging Economies, 6(2), http://dx.doi.org/10.1108/JAEE-03-2014-0015.

Vafeas, N. (1999). Board meeting frequency and firm performance. Journal of Financial Economics, 53(1), 113-142.

Yamani, A., Hussainey, K, \& Albitar K. (2021). Does governance affect compliance with IFRS 7? Journal of Risk and Financial Management, 14, 239.

Zango, A., Kamardin, H., \& Ishak, R. (2016). Audit quality, board gender and financial risk disclosure. International Journal of Economics and Financial Issues, 6(4), 5561 . 